\title{
PRINCIPLE COMPONENT ANALYSIS (PCA) OF BEAN GENOTYPES (Phaseolus vulgaris L.) CONCERNING AGRONOMIC, MORPHOLOGICAL AND BIOCHEMICAL CHARACTERISTICS
}

\author{
GIRGEL, U. \\ Kahramanmaras Sutcu Imam University, Goksun Vocational School, Goksun, Kahramanmaras, \\ Turkey \\ e-mail: umitgirgel@ksu.edu.tr; phone:+90-344-300-1536 \\ (Received $5^{\text {th }}$ Jan 2021; accepted $18^{\text {th }}$ Mar 2021)
}

\begin{abstract}
This study was established in Bayburt University with 3 replications according to the Randomized Complete Block Design (RCBD) pattern in Bayburt University Organic Agriculture Research and Application Treatment Area in order to determine the agro-morphological, biochemical and quality characteristics of 5 local bean (Phaseolus vulgaris L.) genotypes (Aydintepe, Mollakoy, Konursu, Yukarikirzi, Suludere) and 2 registered bean varieties (Ala Ciftci, Mispir). During the research, Principle Component Analysis (PCA) was performed on dry bean genotypes. The first principal component had $37.899 \%$ of the total variation (PC1). The second principle component (PC2) explained $19.975 \%$ of the total variation. The third principle component had 15.906 of the total variation (PC3). The cumulative ratio of the three primary components in total variation was $73.780 \%$. In the first principle component, Carotenoid (0.905), Chlorophyll-B (0.798), Pod Number per Plant (0.745), Pod Length (0.701), Chlorophyll-C (0.684), Chlorophyll-A (0.608), Branch Number (0.563), First Pod Height (0.491) and Thousand Seed Weight $(0.314)$ had the highest coefficients. The genotypes used in the study differ greatly from each other in terms of agronomic, morphological and biochemical characteristics. This is important for breeders trying to create variability, and it may be recommended to include these genotypes as genitors in breeding studies.
\end{abstract}

Keywords: local genotypes, variety, Phaseolus vulgaris L., Principle Component Analysis (PCA)

\section{Introduction}

Bean (Phaseolus vulgaris L.) is an edible legume plant belonging to The Leguminosae family. It has been reported by researchers that in the family, beans are the commonly produced species in the world (Singh et al., 2007). Leguminosae family is the second commonly important family in agriculture after Gramineae family. Although grains are a very important source of energy, legumes are an important source of protein for humanity (Singh, 2005, 2007). This family meets 33 percent of human protein needs (Graham and Vance, 2003). On the other hand, Phaseolus species are important worldwide for human and animal consumption (Graham and Ranalli, 1997; Logozzo et al., 2007; AquinoBolanos et al., 2016). Beans are consumed as canned and frozen as well as fresh and dried beans (Paredes et al., 2009).

Lewis et al. (2005), reported that legumes include agroforestry species, oilseed crops, major grain legumes, ornamental crops, forage crops etc.

Legumes are economically important because it is used in world trade as linoleum, chemicals, lubrication, paints, ethanol coatings, pharmaceutical products, soap, resins, cosmetics, plastic coatings etc. (Singh et al., 2007).

Beans are grown on five continents and these continents are Asia, North and South America, East Africa and West-Southeast Europe (Siemonsma and Na Lapang, 1992). According to 2018 data in the world, 33 million hectares of dry beans were harvested and 28.9 million tons were produced. In the same year 225 thousand tons of dry bean 
production was performed in 89 thousand hectares of land in Turkey. Yield for dry bean in the world was $874 \mathrm{~kg} / \mathrm{ha}$ and in Turkey was $2531 \mathrm{~kg} / \mathrm{ha}$ (FAO, 2019).

Central America (Mesoamerica) and South America (Andea) regions are the bean gene pools (Gepts, 1998; Checa et al., 2006; Angioi et al., 2010; Bitocchi et al., 2012; Cortes, 2013). The Central America (Mesoamerica) gene pool extends from Mexico to Colombia, and the South America (Andea) gene pool extends from Southern Peru to Northwest Argentina (De la Funte, 2012). Dry beans (Phaseolus vulgaris L., $2 \mathrm{n}=2 \mathrm{x}=22$ ) are a type of self-pollinated product (Yeken et al., 2018).

After the beans were cultured, many genotypes that differ in morpho-agronomic characteristics were developed and this diversity is used in breeding and expansion of the gene pool (Sinkovic et al., 2019).

Principal Component Analysis (PCA) is a multivariate statistical technique that aims to reduce the dimensionality of high dimensional data sets (Wiley, 1981). It does so by computing much smaller variables (Principle Components) that represent the original data set. Each new variable is a linear combination of the original variables. The first principle component is the linear combination of original variables that explains the maximum amount of variance. The second principal component is perpendicular to the first principal component and describes the maximum amount of remaining variance in the data. All essential components are perpendicular to each other, so there is no unnecessary information (Dona et al., 2009).

Difficulty may be encountered in interpreting and summarizing analysis results with too many variables. In such cases, principal component analysis (PCA), one of the multivariate statistical methods, is widely used (Sangun, 2007). In this way, principal component analysis has been used in many studies (Rencher, 2002; Marcus, 2004; Pierce et al., 2006; Shittu et al., 2007; Widodo et al., 2007; Madakbas and Ergin, 2011; Rencher and Christensen, 2012; Canci et al., 2019). On the other hand, Principal Component Analysis (PCA), which is used to eliminate the dependency structure between variables or for dimension reduction, is used as an analysis used alone, as well as a data preparation technique for other analyzes (Sharma, 1996). On the other hand, PCA analysis in dry bean was used to calculate the Euclidean distances between cultivars (Adams, 1977).

This research was carried out in order to obtain information that could be the basis for future cultivar development studies in the bean plant. For this purpose, important Agronomic, morphological and biochemical characteristics of bean genotypes and standard varieties collected from different locations were examined and the PCA analysis results of these characteristics were presented.

\section{Materials and Methods}

\section{Site Description}

In this study was established in Bayburt University Aydintepe Vocational School Research Area (40²4'05.7' N, 4008'31.3” E) in Turkey. In the research, Aydintepe, Ala Ciftci, Mollakoy, Konursu, Mispir, Yukarikirzi, Suludere bean (Phaseolus vulgaris L.) genotypes were used. Two of them (Ala Ciftci, Mispir) were registered bean variety and the others are local bean genotypes. 


\section{Experiment}

The experiment was laid out in a randomized complete block design (RCBD) with three replications with 3 replications. 4 rows of planting were made in each plot, and the seeds were planted by hand at a depth of $5-6 \mathrm{~cm}$ in rows opened with a marker and $50 \mathrm{~cm}$ between inter-row spacing and $10 \mathrm{~cm}$ intra-row spacing was used (The plot size is $5.0 \mathrm{~m} \mathrm{x} 0.5 \mathrm{~m} \mathrm{x}$ 4 row $=10 \mathrm{~m}^{2}$ ). According to Sehirali (1988), the water requirement of the bean plant depending on the climatic conditions was provided by the sprinkler system. Weeds were destroyed manually according to the situation in the environment. On the other hand, 6.0 $\mathrm{kg} \mathrm{P}_{2} \mathrm{O}_{5}$ and $2.5 \mathrm{~kg} \mathrm{~N}$ per decare fertilizer was used at the time of planting. Growing rules for bean plants were applied equally to all plots (Meral et al., 1998; Bozoglu et al., 2002; Karadavut et al., 2011; Sozen et al., 2012; Sozen and Karadavut, 2016; Girgel and Cokkizgin, 2019).

\section{Measurements}

The following features measured according to Hardwick et al. (1978), IBPGR (1982), Berrocal-Ibarra et al. (2002), Karadavut et al. (2011) Asemanrafat and Honar (2017), Boydston et al. (2018), Saleh et al. (2018); the sample was taken on ten plants and its average was determined plant height, stem diameter, branch number, first pod height, pod length, pod width, pod number per plant, seed number per pod. It was decided to reach $50 \%$ of the plot for the following features, number of days to emergence, number of days to flowering, number of days to physiological maturity. Thousand seed weight was calculated according to this: 100 seeds were counted 4 times; the average was taken and multiplied by 10 (Girgel and Cokkizgin, 2019). The seed yield value was found by converting into $\mathrm{kg} / \mathrm{ha}$ with proportion after the plots were harvested (Hardwick et al., 1978; Meral et al., 1998; Karadavut et al., 2011; Sozen and Karadavut, 2016; Girgel and Cokkizgin, 2019).

Chlorophyll-A, Chlorophyll-B, Chlorophyll-C, carotenoid, proline, malondialdehyde, total phenolic compounds parameters determined according to Chandler and Dodds (1983), Lichtenthaler (1987), and Kabbadj et al. (2017).

\section{Statistical Analyses}

The effect levels of the characters determining Principle Component Analysis (PCA) and Correlation Coefficient Analysis. PCA and Correlation coefficients were calculated using the xlstat statistical analysis program, which is a program that uses the Microsoft Excel infrastructure (XLSTAT, 2020).

\section{Results and Discussions}

\section{Summary Statistics}

According to results; number of days to emergence, number of days to flowering, plant height, stem diameter, branch number, first pod height, pod length, pod width, pod number per plant, seed number per pod, thousand seed weight, seed yield, number of days to physiological maturity, chlorophyll-a, chlorophyll-b, chlorophyll-b, carotenoid, proline, malondialdehyde, total phenolic compounds varied between 11.667-20.000 day, 58.00069.333 day, 39.473-42.967 cm, 3.603-4.837 mm, 2.667-4.000 number, $15.433-18.700 \mathrm{~cm}$, 9.000-11.587 cm, 1.320-1.810 cm, 2.333-4.000 number, 3.333-5.333 number, 341.667$450.333 \mathrm{~g}, 877.33-1546.67 \mathrm{~kg} / \mathrm{ha}, 115.667-127.000$ day, $210.947-282.526 \mu \mathrm{g} / \mathrm{g}, 82.023-$ $128.235 \mu \mathrm{g} / \mathrm{g}, 126.287-159.569 \mu \mathrm{g} / \mathrm{g}, 0.696-1.578 \mu \mathrm{g} / \mathrm{g}, 1.120-1.926 \mu \mathrm{mol} / \mathrm{gr}, 1.577-2.796$ 
nmol/g, 19.210-23.434 mmol GA/g, respectively (Table 1). These results were found to be lower than what they obtained in the Bilashini Devi et al. (2018) study. This situation is the result of plant genetics, climate and environmental factors. Our findings are in agreement with other studies (Kamaluddin and Ahmed, 2011; Madakbas and Ergin, 2011; Gopinath et al., 2014; Hosseinpour et al., 2014; Aydogan, 2017; Kadioglu et al., 2020).

Table 1. Summary Statistics for Bean Genotypes

\begin{tabular}{c|c|c|c|c}
\hline Variable & Minimum & Maximum & Mean & Std. deviation \\
\hline NDE & 11.667 & 20.000 & 16.095 & 2.904 \\
NDUF & 58.000 & 69.333 & 63.095 & 4.086 \\
PH & 39.473 & 42.967 & 41.209 & 1.265 \\
SD & 3.603 & 4.837 & 4.103 & 0.500 \\
BN & 2.667 & 4.000 & 3.114 & 0.418 \\
FPH & 15.433 & 18.700 & 16.650 & 1.161 \\
PL & 9.000 & 11.587 & 10.190 & 0.858 \\
PW & 1.320 & 1.810 & 1.507 & 0.168 \\
PNPP & 2.333 & 4.000 & 3.305 & 0.589 \\
SNPP & 3.333 & 5.333 & 4.219 & 0.710 \\
TSW & 341.667 & 450.333 & 401.667 & 46.187 \\
SY & 877.33 & 1546.67 & 123.976 & 25.813 \\
NDPM & 115.667 & 127.000 & 123.810 & 4.264 \\
CHL-A & 210.947 & 282.526 & 255.054 & 22.870 \\
CHL-B & 82.023 & 128.235 & 102.275 & 16.229 \\
CHL-C & 126.287 & 159.569 & 144.333 & 12.493 \\
CARO & 0.696 & 1.578 & 1.094 & 0.269 \\
PROL & 1.120 & 1.926 & 1.531 & 0.254 \\
MDA & 1.577 & 2.796 & 2.036 & 0.437 \\
TPC & 19.210 & 23.434 & 21.855 & 1.437 \\
\hline
\end{tabular}

NDE:Number of days to emergence (day), NDUF:Number of days to flowering (day), PH: Plant height $(\mathrm{cm})$, SD:Stem diameter (mm), BN:Branch number (number), FPH:First pod height (cm), PL:Pod lenght $(\mathrm{cm})$, PW:Pod width (cm), PNPP:Pod number per plant (number), SNPP:Seed number per pod (number), TSW:Thousand seed weight $(\mathrm{g})$, SY:Seed yield $(\mathrm{kg} / \mathrm{ha})$, NDPM:Number of days to physiological maturity (day), CHL-A:Chlorophyll-A ( $\mu \mathrm{g} / \mathrm{g})$, CHL-B:Chlorophyll-B ( $\mu \mathrm{g} / \mathrm{g})$, CHL-C:Chlorophyll-B $(\mu \mathrm{g} / \mathrm{g})$, CARO:Carotenoid ( $\mu \mathrm{g} / \mathrm{g})$, PROL:Proline ( $\mu \mathrm{mol} / \mathrm{gr})$, MDA: Malondialdehyde $(\mathrm{nmol} / \mathrm{g})$, TPC:Total phenolic compounds (mmol GA/g)

\section{Correlation Coefficient Analysis}

According to the correlation coefficient analysis (Pearson, 1900), positive-significant relationships were found between number of days to flowering and Malondialdehyde $(\mathrm{r}=0.854)$, stem diameter and branch number $(\mathrm{r}=0.757)$, first pod height and carotenoid $(\mathrm{r}=0.772)$, pod length and pod number per plant $(\mathrm{r}=0.870)$, seed number per pod and thousand seed weight ( $\mathrm{r}=0.765)$, Chlorophyll-A and Chlorophyll-B ( $\mathrm{r}=0.866)$, Chlorophyll-A and Chlorophyll-C ( $\mathrm{r}=0.909)$, Chlorophyll-A and Carotenoid $(\mathrm{r}=0.861)$, Chlorophyll-B and Chlorophyll-C ( $\mathrm{r}=0.843)$, Chlorophyll-B and Carotenoid ( $\mathrm{r}=0.884)$, Chlorophyll-C and Carotenoid ( $\mathrm{r}=0.814$ ) (Table 2). Especially chlorophyll A, chlorophyll $\mathrm{B}$, and chlorophyll $\mathrm{C}$ were found to be positively correlated as they are properties associated with photosynthesis. In terms of agronomical characters' correlation coefficients were similar to Tofiq et al. (2016) results. On the other hand, similar views were reported regarding the correlation coefficients between yield components (Aydogan, 2017). This situation reveals that there is a close relationship between biochemical characters especially between Chlorophyll elements with Carotenoid. 
Table 2. Correlation matrix (Pearson (n))

\begin{tabular}{|c|c|c|c|c|c|c|c|c|c|c|c|c|c|c|c|c|c|c|c|}
\hline Variables & NDE & NDUF & $\mathrm{PH}$ & SD & $\mathrm{BN}$ & FPH & PL & PW & PNPP & SNPP & TSW & SY & NDPM & CHL-A & CHL-B & CHL-C & CARO & PROL & MDA \\
\hline NDUF & -0.135 & & & & & & & & & & & & & & & & & & \\
\hline $\mathrm{PH}$ & 0.329 & -0.604 & & & & & & & & & & & & & & & & & \\
\hline SD & -0.342 & 0.006 & -0.110 & & & & & & & & & & & & & & & & \\
\hline $\mathrm{BN}$ & -0.291 & 0.118 & 0.162 & 0.757 & & & & & & & & & & & & & & & \\
\hline FPH & 0.067 & 0.303 & 0.430 & 0.201 & 0.734 & & & & & & & & & & & & & & \\
\hline PL & 0.237 & 0.265 & -0.138 & -0.405 & -0.497 & -0.298 & & & & & & & & & & & & & \\
\hline PW & 0.229 & 0.208 & -0.294 & 0.305 & 0.267 & 0.013 & 0.456 & & & & & & & & & & & & \\
\hline PNPP & 0.279 & -0.145 & -0.057 & -0.379 & -0.699 & -0.650 & 0.870 & 0.303 & & & & & & & & & & & \\
\hline SNPP & 0.374 & -0.655 & 0.566 & 0.327 & 0.461 & 0.300 & -0.556 & 0.126 & -0.378 & & & & & & & & & & \\
\hline TSW & 0.737 & -0.233 & 0.403 & -0.057 & 0.211 & 0.423 & -0.412 & 0.074 & -0.391 & 0.765 & & & & & & & & & \\
\hline SY & 0.433 & -0.248 & 0.365 & 0.562 & 0.256 & 0.118 & -0.141 & 0.108 & 0.023 & 0.460 & 0.347 & & & & & & & & \\
\hline NDPM & 0.575 & -0.389 & 0.736 & -0.250 & 0.083 & 0.352 & 0.332 & 0.336 & 0.273 & 0.489 & 0.448 & 0.179 & & & & & & & \\
\hline CHL-A & -0.146 & 0.302 & 0.168 & 0.294 & 0.469 & 0.633 & -0.654 & -0.554 & -0.788 & 0.078 & 0.238 & 0.260 & -0.338 & & & & & & \\
\hline CHL-B & 0.119 & -0.007 & 0.370 & 0.521 & 0.563 & 0.583 & -0.679 & -0.340 & -0.678 & 0.453 & 0.472 & 0.667 & -0.095 & 0.866 & & & & & \\
\hline CHL-C & -0.091 & 0.160 & 0.020 & 0.351 & 0.455 & 0.469 & $-\mathbf{0 . 8 5 7}$ & -0.484 & -0.881 & 0.283 & 0.418 & 0.243 & -0.441 & 0.909 & 0.843 & & & & \\
\hline CARO & 0.015 & -0.081 & 0.548 & 0.297 & 0.623 & 0.772 & -0.748 & -0.452 & -0.823 & 0.514 & 0.518 & 0.334 & 0.083 & 0.861 & 0.884 & 0.814 & & & \\
\hline PROL & -0.495 & -0.717 & 0.065 & 0.078 & -0.212 & -0.619 & -0.219 & -0.310 & 0.169 & 0.117 & -0.404 & -0.149 & -0.202 & -0.346 & -0.282 & -0.215 & -0.231 & & \\
\hline MDA & 0.010 & 0.854 & -0.572 & -0.105 & -0.239 & -0.059 & 0.639 & 0.264 & 0.356 & -0.813 & -0.436 & -0.085 & -0.300 & -0.014 & -0.224 & -0.210 & -0.429 & -0.574 & \\
\hline TPC & 0.484 & 0.217 & -0.194 & -0.730 & -0.881 & -0.437 & 0.466 & -0.260 & 0.518 & -0.510 & -0.012 & -0.112 & -0.112 & -0.153 & -0.286 & -0.194 & -0.403 & -0.234 & 0.487 \\
\hline
\end{tabular}

Values in bold are different from 0 with a significance level alpha $=0.05$.

NDE:Number of days to emergence (day), NDUF:Number of days to flowering (day), PH: Plant height (cm), SD:Stem diameter (mm), BN:Branch number (number), FPH:First pod height $(\mathrm{cm})$, PL:Pod lenght $(\mathrm{cm})$, PW:Pod width $(\mathrm{cm})$, PNPP:Pod number per plant (number), SNPP:Seed number per pod (number), TSW:Thousand seed weight (g), SY:Seed yield (kg/ha), NDPM:Number of days to physiological maturity (day), CHL-A:Chlorophyll-A ( $\mu \mathrm{g} / \mathrm{g})$, CHL-B:Chlorophyll-B ( $\mu \mathrm{g} / \mathrm{g}$ ), CHLC:Chlorophyll-B ( $\mu \mathrm{g} / \mathrm{g}$ ), CARO:Carotenoid ( $\mu \mathrm{g} / \mathrm{g})$, PROL:Proline ( $\mu \mathrm{mol} / \mathrm{gr})$, MDA: Malondialdehyde (nmol/g), TPC:Total phenolic compounds (mmol GA/g) 


\section{Principal Component Analysis}

Principal component analysis (PCA), which is a size reduction method using the data set of the studied agricultural characteristics, applied. All of the total variation has been derived from 6 principal component axis and Eigenvalues, Variability values (\%) and Cumulative values (\%) showed that Table 3. The first principal component had $37.899 \%$ of the total variation (PC1). The second principle component (PC2) explained $19.975 \%$ of the total variation. The third principle component had 15.906 of the total variation (PC3). The cumulative ratio of the three primary components in total variation was $73.780 \%$. The rest of principle components (PC4=12.710\%, PC5 $=7.689 \%$ and PC6 $=5.821 \%$ ) had $26.22 \%$ of the total variation. As a result of the PCA analysis, 6 principle component axes were obtained and these axes represented all of the total variation. The 6 principle components explained $100 \%$ of the total variation. Madakbas and Ergin (2011) also reported that all variations were explained with the first 6 principle components in their work.

Table 3. Eigenvalues, Variability and Cumulative Values

\begin{tabular}{c|c|c|c|c|c|c}
\hline & PC1 & PC2 & PC3 & PC4 & PC5 & PC6 \\
\hline Eigenvalue & 7.580 & 3.995 & 3.181 & 2.542 & 1.538 & 1.164 \\
Variability \% & 37.899 & 19.975 & 15.906 & 12.710 & 7.689 & 5.821 \\
Cumulative \% & 37.899 & 57.874 & 73.780 & 86.489 & 94.179 & 100.000 \\
\hline
\end{tabular}

Scree Plot (Graphical representation of Eigenvalues) was given in Fig. 1. Eigenvalues were 7.580 for PC1 and 3.995 (PC2), 3.181 (PC3), 2.542 (PC4), 1.538 (PC5) and 1.164 (PC6), respectively. If the eigenvalues are above 1, it indicates that the evaluated principal component weight values are reliable (Mohammadi and Prasanna, 2003). On the other, Iezzoni and Pritts (1991) reported that if the eingenvalue value is greater than 1 (PCs with eigenvalue $>1.0$ ), it is more informative than the original variable.

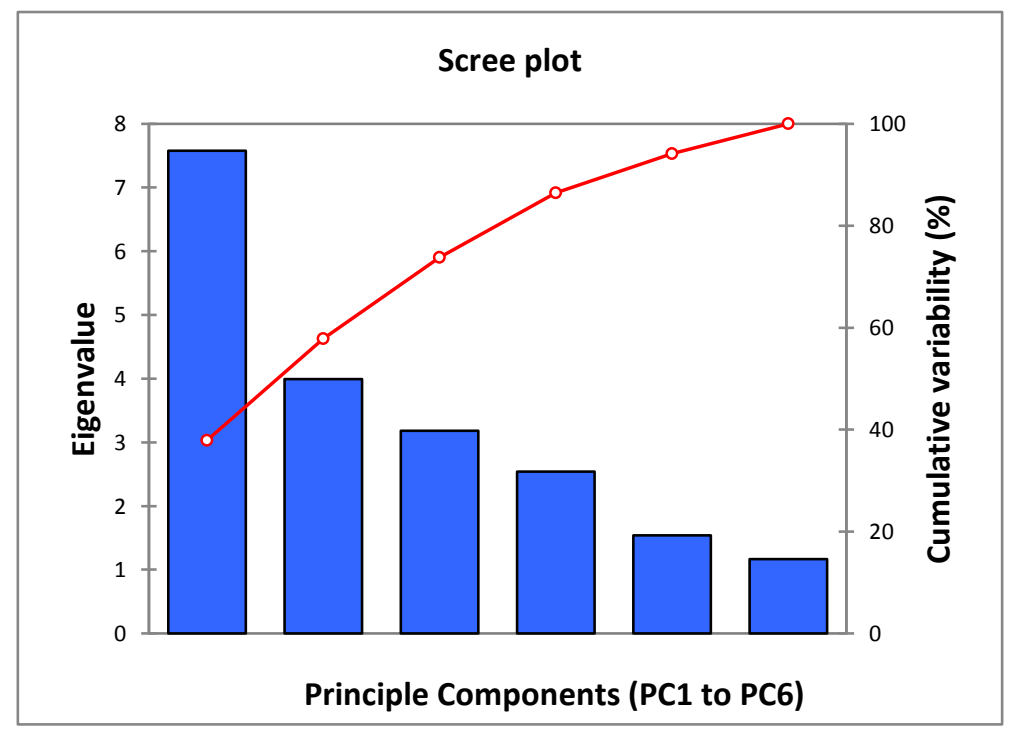

Figure 1. Graphical representation of Eigenvalues 
When this biplot is examined (Fig. 2), there is a positive relationship between the narrow angle features, for example NDPM with NDE or CARO with CHL-B etc. Rightangle features are not related to each other, for example CARO with NDPM. Wide-angle features have negative relationships with each other for example CARO with PNPP etc. The biplot technique enables the determination of the relationships between the variables as well as the detailed description of a multivariate data set (Yan and Rajcan, 2002).

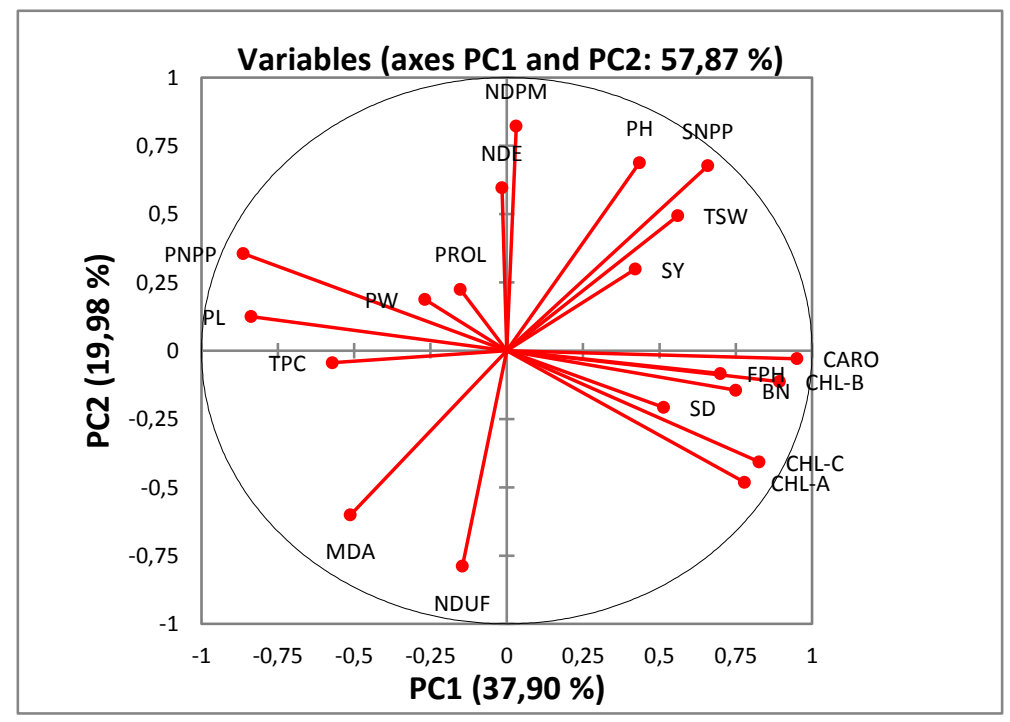

Figure 2. Principal Component Analysis (PCA) biplot showing the distribution of agronomic, morphological and biochemical characteristics in the first principle component and the second principle component. NDE:Number of days to emergence (day), NDUF:Number of days to flowering (day), PH: Plant height ( $\mathrm{cm}$ ), SD:Stem diameter ( $\mathrm{mm}$ ), BN:Branch number (number), FPH:First pod height (cm), PL:Pod lenght (cm), PW:Pod width (cm), PNPP:Pod number per plant (number), SNPP:Seed number per pod (number), TSW:Thousand seed weight (g), SY:Seed yield (kg/ha), NDPM:Number of days to physiological maturity (day), CHL-A:Chlorophyll-A $(\mu \mathrm{g} / \mathrm{g})$, CHL-B:Chlorophyll-B $(\mu \mathrm{g} / \mathrm{g})$, CHL-C:Chlorophyll-B $(\mu \mathrm{g} / \mathrm{g})$, CARO:Carotenoid $(\mu \mathrm{g} / \mathrm{g})$, PROL:Proline ( $\mu \mathrm{mol} / \mathrm{gr}$ ), MDA: Malondialdehyde (nmol/g), TPC:Total phenolic compounds ( $\mathrm{mmol} \mathrm{GA/g}$ )

In the first principle component, CARO (0.905), CHL-B (0.798), PNPP (0.745), PL (0.701), CHL-C (0.684), CHL-A (0.608), BN (0.563), FPH (0.491) and TSW (0.314) had the highest coefficients, respectively (Table 4). In the second principle component, NDPM (0.677), NDUF (0.623), PH (0.474), SNPP (0.458), MDA (0.362) had the highest coefficients, respectively. For the third principle component PROL (0.903), NDE (0.484) had the highest coefficients, respectively. On the other hand, in the fourth principle component PW (0.701), TPC (0.456), SD (0.418) had the highest coefficients. In the fifth essential component SY (0.539) had the highest coefficients. Yeken et al. (2019) reported that the principle component values obtained from botanical features at these levels.

When the biplot graph of the genotypes used in the study is examined (Fig. 3), it is seen that the genotypes are quite different from each other and they are distributed in the graph. It is possible to say that only Ala Ciftci and Aydintepe genotypes can be similar. This situation can be fully explained by the reflection of genetic factors on the studied parameters (agronomic, morphological and biochemical characteristics). Similar results gained by Madakbas et al. (2006). 


$$
\text { - } 2006 \text { - }
$$

Table 4. Principle component analysis results of the studied agronomic, morphological and biochemical characteristics

\begin{tabular}{c|c|c|c|c|c|c}
\hline & PC1 & PC2 & PC3 & PC4 & PC5 & PC6 \\
\hline NDE & 0.000 & 0.356 & $\mathbf{0 . 4 8 4}$ & 0.050 & 0.071 & 0.039 \\
NDUF & 0.021 & $\mathbf{0 . 6 2 3}$ & 0.312 & 0.027 & 0.013 & 0.004 \\
PH & 0.189 & $\mathbf{0 . 4 7 4}$ & 0.004 & 0.036 & 0.060 & 0.238 \\
SD & 0.265 & 0.043 & 0.054 & $\mathbf{0 . 4 1 8}$ & 0.205 & 0.014 \\
BN & $\mathbf{0 . 5 6 3}$ & 0.021 & 0.000 & 0.391 & 0.024 & 0.001 \\
FPH & $\mathbf{0 . 4 9 1}$ & 0.007 & 0.221 & 0.039 & 0.220 & 0.023 \\
PL & $\mathbf{0 . 7 0 1}$ & 0.016 & 0.152 & 0.046 & 0.004 & 0.082 \\
PW & 0.072 & 0.035 & 0.095 & $\mathbf{0 . 7 0 1}$ & 0.011 & 0.086 \\
PNPP & $\mathbf{0 . 7 4 5}$ & 0.126 & 0.007 & 0.002 & 0.049 & 0.071 \\
SNPP & 0.434 & $\mathbf{0 . 4 5 8}$ & 0.009 & 0.020 & 0.010 & 0.069 \\
TSW & $\mathbf{0 . 3 1 4}$ & 0.244 & 0.191 & 0.030 & 0.003 & 0.218 \\
SY & 0.177 & 0.089 & 0.057 & 0.019 & $\mathbf{0 . 5 3 9}$ & 0.118 \\
NDPM & 0.001 & $\mathbf{0 . 6 7 7}$ & 0.133 & 0.038 & 0.120 & 0.030 \\
CHL-A & $\mathbf{0 . 6 0 8}$ & 0.232 & 0.031 & 0.091 & 0.000 & 0.038 \\
CHL-B & $\mathbf{0 . 7 9 8}$ & 0.013 & 0.034 & 0.017 & 0.096 & 0.042 \\
CHL-C & $\mathbf{0 . 6 8 4}$ & 0.166 & 0.001 & 0.097 & 0.023 & 0.029 \\
CARO & $\mathbf{0 . 9 0 5}$ & 0.001 & 0.011 & 0.038 & 0.022 & 0.024 \\
PROL & 0.023 & 0.050 & $\mathbf{0 . 9 0 3}$ & 0.010 & 0.007 & 0.006 \\
MDA & 0.262 & $\mathbf{0 . 3 6 2}$ & 0.311 & 0.016 & 0.019 & 0.031 \\
TPC & 0.327 & 0.002 & 0.172 & $\mathbf{0 . 4 5 6}$ & 0.042 & 0.002 \\
\hline
\end{tabular}

Values in bold correspond for each variable to the factor for which the squared cosine is the largest

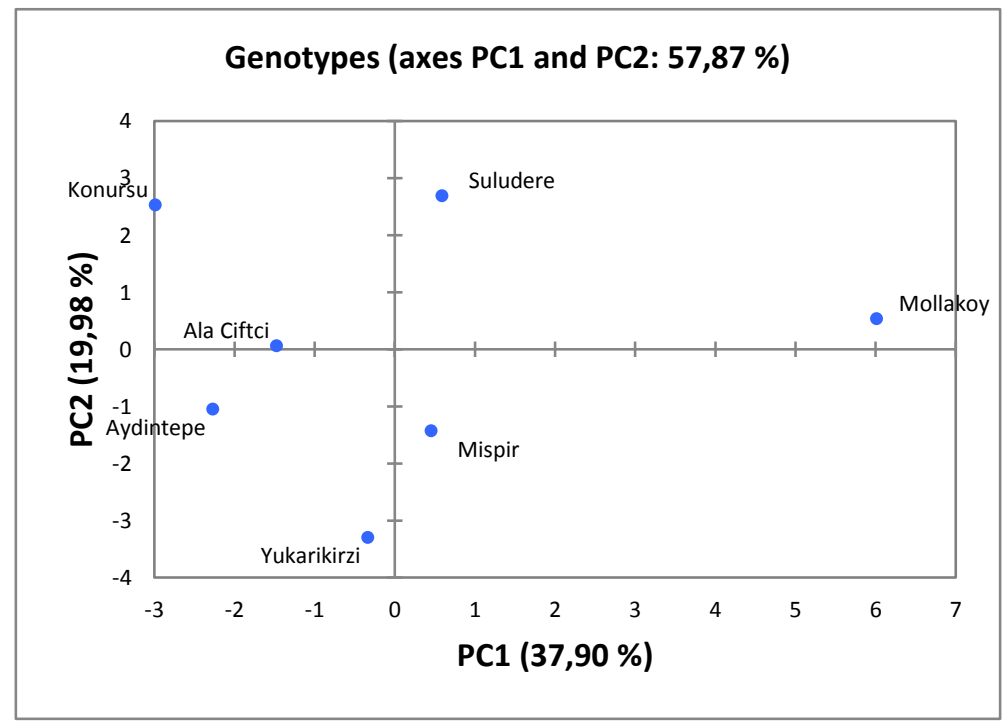

Figure 3. Principal Component Analysis (PCA) biplot showing the distribution of bean genotypes in the first principle component and the second principle component

The graphic in which the biplots of bean genotypes were combined with the examined agronomic, morphological, biochemical characteristics was given in Fig. 4. In this graph, as stated above, while narrow angle features have a positive relationship, wide angles have a negative relationship, while there is no correlation between right angles. On the 
other hand, similarly the Euclidean distances between cultivars were used to calculate in dry bean (Adams, 1977).

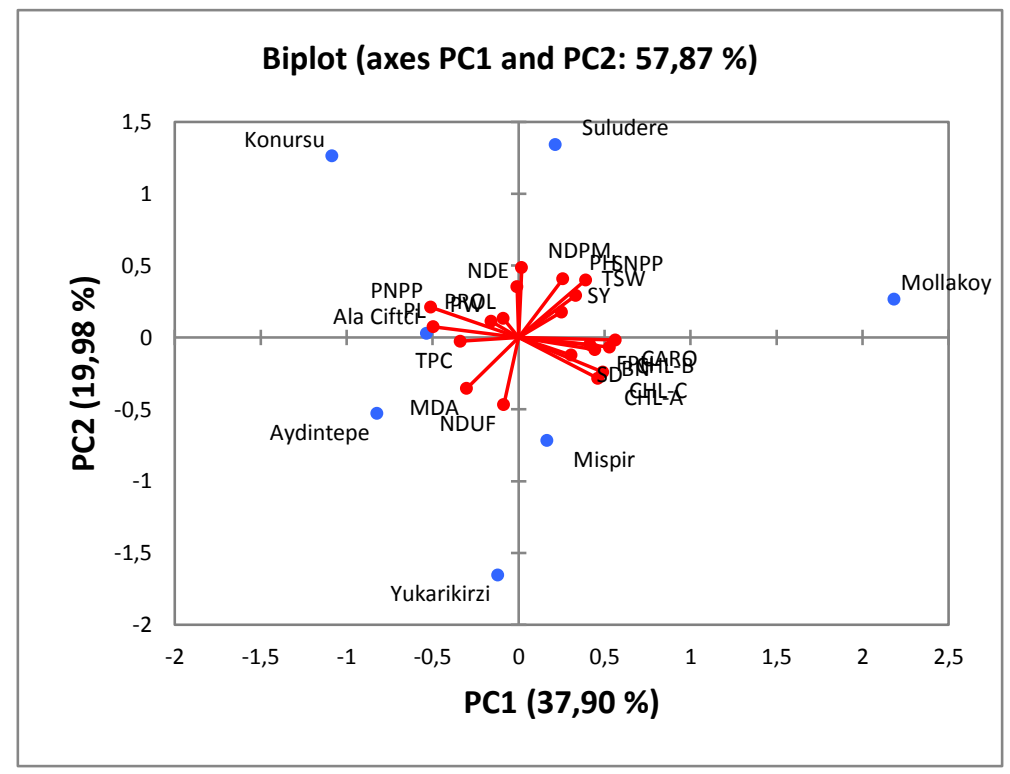

Figure 4. Principal Component Analysis (PCA) biplot of the agronomic, morphological and biochemical characteristics of local bean genotypes for the first two principle components

In terms of the genotypes PCA analysis results was given in Table 5. According to it; Mollakoy (0.921) and Konursu (0.411) have the highest coefficient value in the first Principle Component (PC1). In the second Principle Component (PC2), Yukarikirzi and Suludere had the highest coefficient values (0.651 and 0.438 respectively). Ala Ciftci (0.599) and Aydintepe (0.543) genotypes are the genotypes with the highest coefficient in the third Principle Component (PC3). And finally, the Mispir registered bean variety in the sixth Principle Component (PC6) had a high coefficient value (0.393). It stated that the populations differ more from each other. It is stated that Turkey is considered rich in beans biodiversity (Canci et al., 2019). Ashgari and Vojdani (1997), as a result of their studies, it has been determined that climate diversity and genetic difference were closely related.

Table 5. Principle component analysis results of the bean genotypes

\begin{tabular}{c|c|c|c|c|c|c}
\hline & PC1 & PC2 & PC3 & PC4 & PC5 & PC6 \\
\hline Aydintepe & 0.267 & 0.058 & $\mathbf{0 . 5 4 3}$ & 0.027 & 0.046 & 0.059 \\
Ala Ciftci & 0.138 & 0.000 & $\mathbf{0 . 5 9 9}$ & 0.011 & 0.217 & 0.036 \\
Mollakoy & $\mathbf{0 . 9 2 1}$ & 0.007 & 0.000 & 0.067 & 0.004 & 0.000 \\
Konursu & $\mathbf{0 . 4 1 1}$ & 0.295 & 0.005 & 0.205 & 0.025 & 0.059 \\
Mispir & 0.019 & 0.189 & 0.048 & 0.305 & 0.045 & $\mathbf{0 . 3 9 3}$ \\
Yukarikirzi & 0.007 & $\mathbf{0 . 6 5 1}$ & 0.087 & 0.007 & 0.238 & 0.010 \\
Suludere & 0.021 & $\mathbf{0 . 4 3 8}$ & 0.017 & 0.400 & 0.079 & 0.044 \\
\hline
\end{tabular}

Values in bold correspond for each variable to the factor for which the squared cosine is the largest 


\section{Conclusions}

It can be said that the genotypes used in the study differ greatly from each other. This is important for breeders trying to create variability, and it may be recommended to include these genotypes as genitors in breeding studies.

The important features in the first principle component, Pod number per plant, Pod length, Branch number, First pod height and Thousand seed weight, should be taken into account in the agronomic, morphological breeding studies. In the future, Carotenoid, Chlorophyll-B, Chlorophyll-C, Chlorophyll-A, properties could be taken into consideration in biochemical breeding studies.

Acknowledgements. Author is very thankful to Bayburt University.

\section{REFERENCES}

[1] Adams, M. W. (1977): An Estimation of Homogeneity in Crop Plants, with Special Reference to Genetic Vulnerability in the Dry Bean, Phaseolus vulgaris. - Euphytica 26: 665-679.

[2] Angioi, S. A., Rau, D., Attene, G., Nanni, L., Bellucci, E., Logozzo, G., Papa, R. (2010): Beans in Europe: origin and structure of the European landraces of Phaseolus vulgaris L. - Theoretical and Applied Genetics 121(5): 829-843.

[3] Aquino-Bolanos, E. N., Garcia-Diaz, Y. D., Chavez-Servia, J. L., Carrillo-Rodriguez, J. C., Vera-Guzman, A. M., Heredia-Garcia, E. (2016): Anthocyanin, polyphenol, and flavonoid contents andantioxidant activity in Mexican common bean (Phaseolus vulgaris L.) landraces. - Emirates Journal of Food and Agriculture 28(8): 581-588.

[4] Asemanrafat, M., Honar, T. (2017): Effect of water stress and plant density on canopy temperature, yield components and protein concentration of red bean (Phaseolus vulgaris L. cv. akhtar). - Int. J. Plant Prod. 11: 241-258.

[5] Ashgari, A., Vojdani, P. (1997): Study of Genetic Diversity of the Iranian Common Bean Land Races in Relation to Geographical. - Hort. Abst. 1(1): 549.

[6] Aydogan, C. (2017): Yield and Quality Activities on Advanced Ispir Dry Bean (Phaseolus vulgaris L.) Lines. - Ataturk University, Graduate School of Natural and Applied Sciences, Department of Field Crops, Cereals and Pulse Crops Master Thesis, 82p.

[7] Berrocal-Ibarra, S., Ortiz-Cereceres, J., Peña-Valdivia, C. B. (2002): Yield components, harvest index and leaf area efficiency of a sample of a wild population and a domesticated variant of the common bean Phaseolus vulgaris. - South African Journal of Botany 68(2): 205-211. https://doi.org/10.1016/S0254-6299(15)30421-X.

[8] Bilashini Devi, M., Thoithoi Devi, M., Jha, A. K., Yumnam, A., Balusamy, A., Verma, V. K., Talang, H. D., Deshmukh, N. A., Rymbai, H., Assumi, S. R. (2018): Yield and Yield Attributes of Garden Pea (Pisum sativum var. hortense L.) as Influenced by Nutrient Management Practices under Agroclimatic Conditions of Meghalaya. - Int. J. Curr. Microbiol. App. Sci. 7(9): 3447-3454. doi: https://doi.org/10.20546/ijcmas.2018.709.427.

[9] Bitocchi, E., Nanni, L., Bellucci, E., Rossi, M., Giardini, A., Zeuli, P. S., Logozzo, G., Stougaard, J., McClean, P., Attene, G. (2012): Mesoamerican origin of the common bean (Phaseolus vulgaris L.) is revealed by sequence data. - Proceedings of the National Academy of Sciences 109(14): 788-796.

[10] Boydston, R. A., Porter, L. D., Chaves-Cordoba, B., Khot, L. R., Miklas, P. N. (2018): The impact of tillage on pinto bean cultivar response to drought induced by deficit irrigation. Soil Tillage Res. 180: 63-72. 
[11] Bozoglu, H., Peksen, A., Peksen, E., Gulumser, A. (2002): Determination of Green Pod Yield and Some Pod Characteristics of Faba Bean (Vicia faba L.) Cultivar/Lines Grown in Different Row Spacings. - Acta Horticulturae 579: 347-350. doi.org/10.17660/ActaHortic.2002.579.58.

[12] Canci, H., Bozkurt, M., Kantar, F., Yeken, M. Z., Ozer, G., Cifci, V. (2019): Investigation and Characterization of Phaseolus Bean Bio-Diversity in Western Anatolia. - KSU J. Agric. Nat. 22 (Suppl. 2): 251-263. DOI:10.18016/ksutarimdoga.vi.579482.

[13] Chandler, S. F., Dodds, J. H. (1983): The Effect of Phosphate, Nitrogen and Sucrose on the Production of Phenolics and Solasodine in Callus Cultures of Solanum laciniatum. - Plant Cell Report 2: 205-208.

[14] Checa, O., Ceballos, H., Blair, M. W. (2006): Generation means analysis of climbing ability in common bean (Phaseolus vulgaris L.). - Journal of Heredity 97(5): 456-465.

[15] Cortes, A. J. (2013): On the origin of the common bean (Phaseolus vulgaris L.). American Journal of Plant Sciences 4(10): 1998-2000.

[16] De la Funte, M., Lopez-Pedrouso, M., Alonso, J., Santalla, M., De Ron, A. M., Alvarez, G., Zapata, C. (2012): In-Depth Characterization of the Phaseolin Protein Diversity of Common Bean (Phaseolus vulgaris L.) Based on Two-Dimensional Electrophoresis and Mass Spectrometry. - Food Technology and Biotechnology 50(3): 315-325.

[17] Dona, G., Preatoni, E., Cobelli, C., Rodano, R., Harrison, A. J. (2009): Application of functional principal component analysis in race walking: An emerging methodology. Sports Biomechanics 8(4): 284-301.

[18] FAO (2019): The Food and Agriculture Organization (FAO) Statistical Database. www.fao.org.

[19] Gepts, P. (1998): Origin and Evolution of Common Bean: Past Events and Recent Trends. - Hort. Science 33(7): 1124-1130.

[20] Girgel, U., Cokkizgin, A. (2019): Effect of Conventional and Organic Farming on Morphological and Agronomic Characteristics of Common Bean (Phaseolus vulgaris L.). - Agriculture-Elixir International Journal 129: 53007-53010.

[21] Gopinath, K. A., Saha, S., Mina, B. L., Pande, H., Kumar, N., Srivastva, A. K., Gupta, H. S. (2014): Yield potential of garden pea (Pisum sativum L.) varieties, and soil properties under organic and integrated nutrient management systems. - Agronomy and Soil Science 55(2): 157-167. DOI: 10.1080/03650340802382207.

[22] Graham, P. H., Ranalli, P. (1997): Common bean (Phaseolus vulgaris L.). - Field Crops Research 53(1-3): 131-146.

[23] Graham, P. H., Vance, C. P. (2003): Legumes: Importance and constraints to greater use. - Plant Physiol. 131: 872-877. doi:10.1104/pp.017004.

[24] Hardwick, R. C., Hardaker, J. M., Innes, N. L. (1978): Yields and components of yield of dry beans (Phaseolus vulgaris L.) in the United Kingdom. - The Journal of Agricultural Science 90(02): 291. doi:10.1017/s0021859600055374.

[25] Hosseinpour, A., Khalilimahalleh, J., Zeinalzadehtabrizi, H., Valilue, R. (2014): Evaluation of Maize and Green Bean Yield in Various Densities and Different Sowing Rates of Intercropping by Replacement Method. - Ataturk Univ., J. of the Agricultural Faculty 45(2): 71-78.

[26] IBPGR (1982): Phaseolus vulgaris Descriptors. - International Board For Plant Genetic Resources (Ibpgr) and International Center For Agricultural Research In The Dry Areas (Icarda), AGPG: IBPGR/81/1. 32p.

[27] Iezzoni, A. F., Pritts, M. P. (1991): Applications Of Principal Component Analysis To Horticultural Research. - HortScience 26(4): 334-338.

[28] Kabbadj, A., Makoudi, B., Mouradi, M., Pauly, N., Frendo, P., Ghoulam, C. (2017): Physiological and biochemical responses involved in water deficit tolerance of nitrogenfixing Vicia faba. - PLoS One 12(12): e0190284. doi: 10.1371/journal.pone.0190284.

[29] Kadioglu, S., Tan, M., Kadioglu, B., Tasgin, G. (2020): Determination of Yield and Some Characteristics of Forage Pea Genotypes (Pisum sativum ssp. arvense L.) under Erzurum 
Conditions. - Atatürk Univ. J. of Agricultural Faculty 51(2): 151-158. doi: 10.17097/ataunizfd.628404.

[30] Kamaluddin, M., Ahmed, S. (2011): Variability, correlation and path analysis for seed yield and yield related traits in common beans. - Indian J. Hort. 68(1): 56-60.

[31] Karadavut, U., Kayıs, S. A., Keskin, I. (2011): Determination of Relationships Between Yield and Yield Components in Some Faba Bean (Vicia Faba L.) Genotypes. - Anatolian Journal of Agricultural Sciences 26(1): 30-35.

[32] Lewis, G., Schrire, B., Mackinder, B., Lock, M. (2005): Legumes of the world. - Royal Botanical Gardens, Kew, Richmond, Surrey, UK. 577p.

[33] Lichtenthaler, H. K. (1987): Chlorophylls and Carotenoids: Pigments of Photosynthetic Biomembranes. - Methods in Enzymology 148: 350-382.

[34] Logozzo, G., Donnoli, R., Macaluso, L., Papa, R., Knupffer, H., Zeuli, P. S. (2007): Analysis of the contribution of Mesoamerican and Andean gene pools to European common bean (Phaseolus vulgaris L.) germplasmand strategies to establish a core collection. - Genetic Resources and Crop Evolution 54(8): 1763-1779.

[35] Madakbas, S. Y., Ozcelik, H., Ergin, M. (2006): Determination of Differences Among the Lines Selected from Dwarf Fresh Bean Populations in The Carsamba Plain. - Harran Journal of Agricultural and Food Science 10(3-4): 71-77.

[36] Madakbas, S. Y., Ergin, M. (2011): Morphological and Phenological Characterization of Turkish Bean (Phaseolus vulgaris L.) Genotypes and Their Present Variation States. African Journal of Agricultural Research 6(28): 6155-6166.

[37] Marcus, M. (2004): Study Guide for M.S. Srivastava's Methods of Multivariate Statistics. - The University of Newcastle, STAT 3010, 219p.

[38] Meral, N., Ciftci, C. Y., Unver, S. (1998): The Effects of Inoculation and Different Doses of Nitrogen Fertilizer On Yield and Yield Components in Chickpea (Cicer arietinum L.). - Biotech Studies 7(1): 44-59.

[39] Mohammadi, S. A., Prasanna, B. M. (2003): Analysis of Genetic Diversity in Crop PlantsSalient Statistical Tools and Considerations. - Crop Sci. 43(4): 1235-1248. https://doi.org/10.2135/cropsci2003.1235.

[40] Paredes, M., Becerra, V., Tay, J. (2009): Inorganic nutritional composition of common bean (Phaseolus vulgaris L.) genotypes race Chile. - Chilean Journal of Agricultural Research 69(4): 486-495.

[41] Pearson, K. F. R. S. (1900): X. On the criterion that a given system of deviations from the probable in the case of a correlated system of variables is such that it can be reasonably supposed to have arisen from random sampling. - Philosophical Magazine Series 5 50(302): 157-175. https://doi.org/10.1080/14786440009463897.

[42] Pierce, K. M., Hope, J. L., Hoggard, J. C., Synovec, R. E. (2006): A Principal Component Analysis Based Method to Discover Chemical Differences in Comprehensive TwoDimensional Gas Chromatography with Time-of-Flight Mass Spectrometry (GCXGCTOFMS) Separation of Metabolites in Plant samples. - Talanta. 70(4): 797-804.

[43] Rencher, A. C. (2002): Methods of Multivariate Analysis. - Second edition, A John Wiley $\&$ Sons, Inc., Publication, 708p.

[44] Rencher, A. C., Christensen, W. F. (2012): Methods of Multivariate Analysis. - Third edition, A John Wiley \& Sons, Inc., Publication, 758p.

[45] Saleh, S., Liu, G., Liu, M., Ji, Y., He, H., Gruda, N. (2018): Effect of irrigation on growth, yield, and chemical composition of two green bean cultivars. - Horticulturae 4(1): 3. doi:10.3390/horticulturae4010003.

[46] Sangun, L. (2007): An Investigation On Principal Component, Discriminant and Cluster Analyses and Their Application On Ecological Data. Department of Aquaculture Science Institute of Natural and Applied Sciences. - Cukurova University, PhD Thesis, 251p.

[47] Sehirali, S. (1988): Grain legume crops. - Ankara University, Faculty of Agricultural Engineering, Ankara, Turkey 1089:314, 435p.

[48] Sharma, S. (1996): Applied Multivariate Techniques. - John Wiley \& Sons, Inc., 509p. 
[49] Shittu, T. A., Sanni, L. O., Awonorin, S. O., Dixon, B. M., Dixon, A. (2007): Use of Multivariate Techniques in Studying the Flour making, Properties of Some CMD Resistant Cassava Clones. - Food Chemistry 101: 1606-1615.

[50] Siemonsma, J. S., Na Lapang, A. (1992): Phaseolus vulgaris L. - In: van der Maesen, L. J. G., Somaatmadja, S. (eds) Plant Resources of South-Asia. pp: 60-63.

[51] Singh, R. J. (2005): Landmark research in grain legumes. - In: Singh, R. J., Jauhar, P. P. (eds.) Genetic Resources, Chromosome Engineering, and Crop Improvement Series: Grain legumes, Vol. 1. CRC Press, Inc., Boca Raton, Fla. pp. 1-9.

[52] Singh, R. J. (2007): Landmark research in oilseed crops. - In Singh, R. J., Jauhar, P. P. (eds.) Genetic Resources, Chromosome Engineering, and Crop Improvement Series: Oilseed crops, Vol. 4. CRC Press, Inc., Boca Raton, Fla. pp. 1-12.

[53] Singh, R. J., Chung, G. H., Nelson, R. L. (2007): Landmark research in legumes. - Genome 50(6): 525-537. doi: 10.1139/g07-037.

[54] Sinkovic, L., Pipan, B., Sinkovic, E., Meglic, V. (2019): Morphological Seed Characterization of Common (Phaseolus vulgaris L.) and Runner (Phaseolus coccineus L.) Bean Germplasm: A Slovenian Gene Bank Example. - BioMed Research International, Article ID: 6376948. https://doi.org/10.1155/2019/6376948.

[55] Sozen, O., Ozcelik, H., Bozoglu, H. (2012): Determination of Biodiversity of Collected Beans (Phaseolus vulgaris L.) Populations in Western Black Sea Region, Turkey. Research Journal of Agricultural Sciences 5(1): 59-63.

[56] Sozen, O., Karadavut, U. (2016): Determination of Morphological and Phenological Properties of Faba Beans Grown in Eastern Mediterranean Region of Turkey. - Biotech Studies 25(2): 209-217.

[57] Tofiq, S. E., Aziz, O. K., Salih, S. H. (2016): Correlation and Path Coefficient Analysis of Seed Yield and Yield Components in Some Faba Bean Genotypes in Sulaimani Region. ARO-The Scientific Journal of Koya University IV(2): 1-6. DOI: 10.14500/aro.10081.

[58] Widodo, A., Yang, B. S., Han, T. (2007): Combination of Independent Analysis and Support Vector Machines for Intelligent Faults Diagnosis of Induction Motors. - Expert Systems with applications 32: 299-312.

[59] Wiley, E. O. (1981): Phylogenetics: The theory and practice of phylogenetics and systematics. - John Wiley, New York. 452p.

[60] XLSTAT (2020): A complete statistical add-in for Microsoft Excel. - Addinsoft SARL, Paris, France, 1528p.

[61] Yan, W., Rajcan, I. (2002): Biplot analysis of test sites and trait relations of soybean in Ontario. - Crop Science 42: 11-20.

[62] Yeken, M. Z., Kantar, F., Canci, H., Ozer, G., Cifci, V. (2018): Breeding of Dry Bean Cultivars Using Phaseolus vulgaris Landraces in Turkey. - International Journal of Agriculture and Wildlife Science (IJAWS) 4(1): 45-54. doi: 10.24180/ijaws.408794.

[63] Yeken, M. Z., Ciftci, V., Canci, H., Ozer, G., Kantar, F. (2019): Morphological Characterization of Common Bean Genotypes Collected from the Western Anatolia Region of Turkey. - International Journal of Agriculture and Wildlife Science (IJAWS) 5(1): 124139. doi: 10.24180/ijaws.529713. 